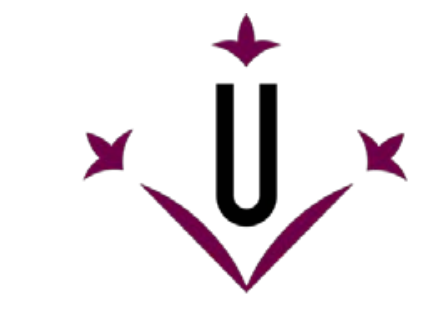

Universitat de Lleida

Document downloaded from:

http://hdl.handle.net/10459.1/67790

The final publication is available at:

https://doi.org/10.1080/14790718.2020.1682246

Copyright

(c)Taylor \& Francis , 2019 


\title{
Marketing University Students as Mobile Multilingual Workers: The Emergence of Neoliberal Lifestylers
}

Maria Sabaté-Dalmau

maria.sabate@dal.udl.cat

Departament d'Anglès i Lingüística,

Universitat de Lleida,

Plaça de Víctor Siurana 1,

25003, Lleida, Catalonia, Spain

[Date received: 21 May 2018, Date accepted: 20 May 2019]

\begin{abstract}
Under the conditions of the globalized new economy, European universities have become profit-making institutions. They envision students as mobile workers-tobe whose employability chances depend on self-enterprising and on self-

responsibilization for foreign-language command, and they now compete in the global educational marketplace by targeting them with an increased offer of internationalized English-mediated 'multilingual' degrees. This paper explores attitudes towards these marketed/marketable studenthood identities by 30 Catalan/Spanish-speaking students enrolled in four Multilingual Studies degrees in Barcelona. The data include students' audio-recorded life-narrative interviews and online 'life-after-graduation' stories collected during a two-year ethnography (2011-2013). The results show that students engage in institutional neoliberal regimes which train them in the academic/professional, linguistic and personhood profiles required in global employment niches. They inhabit unique 'multilingualized' identities, with English as their professional/socialization lingua franca, and they self-attribute open-minded
\end{abstract}


'civic-citizenship' values, with an 'innate' capacity to engage with Otherness. They also invest in 'cosmopolitan' trajectories which blend ways of being, working and enjoying leisure in the transnational arena. This reveals how students position themselves in the precarious job marketplace, in autobiographic e accounts of experience, which contributes to understanding youth identity projections as elite entrepreneurial lifestylers pointing to newer practices of socioeconomic competition, distinction and stratification at university.

Keywords: Higher Education; employability regimes; multilingual policies; neoliberal identities; cosmopolitan lifestyles

\section{Introduction: The Marketization of Higher Education via}

\section{Multilingualization}

Under the conditions of the globalized new economy, the institutions of the European Higher Education Area (EHEA) have turned into profit-making systems which, following market rationalities based on the logics of efficiency, accountability and entrepreneurialism (Duchêne \& Heller, 2012), conceive of students in clienthood terms and manage academic and administrative staff as entrepreneurial Selves (Deem, 2001, Martín Rojo, 2019). As a consequence of this, universities have started to compete to access the educational marketplace by trying to capitalize on two 'missions' grounded on the tenets of educational, economic and linguistic neoliberalism (as defined in Block, 2018): the implementation of 'internationalization' strategies promoting student and staff mobility for academic and professionalization purposes (Sabaté-Dalmau, 2016), and, on the other hand, the institutionalization of 'pro-diversity' language directives which foster the inclusion of global/majority and local/minority languages in the 
curriculum (Llurda, Doiz, \& Sierra, 2015), aimed at the 'multilingualization' of a 'global citizenship' (Codó, 2018a).

The internationalization premises unproblematically assume that geographic mobility (in the form of student stay-abroad programs, for example) propels advantaged success in Higher Education (HE) as well as enhanced possibilities for career development. Similarly, the concomitant language directives targeting the operationalization of the provision of 'multilingual' competence at university follow the view of languages as commodities circulated by the European Council, which envisions European populations as repositories of dominant lingua-franca resources; that is, as a productive transnational multilingual workforce (Flubacher, Duchêne, \& Coray, 2018). These language directives have led to the 'mercantilization' (Fairclough, 2006, p. 73) of multilingual teaching through a process known as ‘Englishization' (Coleman, 2006).

This is a language policy whereby English becomes not only the language of 'internationalization' but also the lingua academica used to 'economicize' the management of linguistic diversity in HE through 'local-language(s)-plus-English' teaching plans (Piller \& Cho, 2013).

All in all, these political and socioeconomically-driven transformations have led to the construction of tertiary education as part and parcel of the language market world. This has had a particular effect on university students, increasingly marketed as entrepreneurial-minded, mobile workers-to-be whose employability chances depend on their competitive self-actualization and flexibility in the mobile marketplace as well as on their self-responsibilization for foreign-language command. In other words, the neoliberalization processes in HE have established models of legitimate studenthood based on the individual's self- investment in market-oriented 'internationalization' and 'multilingualization' via the English-language policies. 
This paper contributes to understanding such transformations by focusing on the students' perspectives on university marketization, as they are in a life-transition stage between educational attainment and job market entrance that may unpack how they (re)shape their sociolinguistic comportments (Pujolar \& Puigdevall, 2015), expanding our knowledge on the emergence of the transnational entrepreneurial Self.

\section{The Present Study}

\subsection{Research Aims}

Following current critical sociolinguistic ethnographic approaches to market-oriented language policies, practices and perspectives in the educational realm (see, e.g., Block, 2018; Codó, 2018b; Codó \& Patiño, 2017; Gao \& Park, 2015), this paper aims to contribute to the exploration of the links between global neoliberalism phenomena and the transformations in the EHEA by investigating the attitudes towards internationalization and Englishization mobilized by a group of 30 Catalan/Spanishspeaking students. These were enrolled in four experimental Multilingual Studies degrees (called Combined Languages Degrees in English; henceforth CLDsE) offered by a top university in Catalonia, the Autonomous University of Barcelona (Universitat Autònoma de Barcelona, in Catalan; henceforth UAB). More specifically, it analyzes their personal life-narrative and autobiographical accounts topicalizing on past, present and projected academic/work and language-learning trajectories, with two aims in mind. Firstly, it tries to unpack the students' positionings towards the deployment of educational/professional mobility programs and English-mediated multilingual directives. Secondly, it seeks to understand the extent to which, how, and why, they invested in neoliberal identity projections of studenthood as internationalized and 
multilingualized self-enterprising workers-to-be.

The overall argument that will be posited throughout the paper is that students engage in the neoliberal 'regimes' (i.e., modes of top-down governance and citizen control; Kroskrity, 2000, p. 3) required in qualified employability niches in the new economy, following their universities' cultural, economic and linguistic market-driven policies and plans. I will show that their narratives of personal experience and of Self reveal how they inhabit highly mobile, multilingual identities possessing unique English-language resources for academic, professional and socialization success, both in transnational work/non-work spaces, on being deeply invested in neoliberalized 'cosmopolitan' (i.e. ego-centered, elitist) lifestyles which blend ways of being, working and enjoying leisure (described in Cohen, Duncan, \& Thulemark, 2015; and Hannerz, 1996, 2004). All in all, the paper will try to shed light on how students narrate the ways in which they position themselves with respect to the challenges of precarious employment conditions by participating in the socioeconomic and political transformations of the EHEA systems. This, I will claim, may contribute to understanding youth identity projections as middle-classed lifestylers pointing to newer practices of competition, distinction, and social stratification on the basis of marketed mobility and hierarchized language-capitalization opportunities (Codó, 2014), in nonEnglish-speaking universities of Southern Europe such as the one presented in Section 2.3 .

\subsection{Theoretical Considerations}

Before presenting the study, the context, the methodology employed and the participants' trajectories, some terminological clarification is in order, with regards to: Attitude, identity, political economy, university policy and planning, and autobiographic 
narrative practice.

In this paper, attitudes are understood as observable indexes of the norms that govern individual/collective everyday-life behaviors (Schieffelin, Woolard, \& Kroskrity, 1998). Similarly, identity categorizations are approached as venues into how individuals negotiate, voice and make sense of who they are, with whom, and why, in a particular time and space (Bamberg, De Fina \& Schiffrin, 2007).

Following a political economic approach to language in social life (Flubacher, Duchêne, \& Coray, 2018), attitudes and identities are conceived of as being ingrained into the 'macro' socioeconomic and political structures (of the EHEA, in this case) and into the situated 'micro' local context in which individuals socialize. In these lines, university policy and planning are envisioned as historicised forms of sociopolitical action (Codó, 2018a) which dictate what tertiary-education models are legitimate for each social segment of the university community.

Finally, autobiographical life narratives allowing for the observation of students' attitudes linked to the political economy of current internationalization and multilingualization policies are understood as windows into how individuals coconstruct (together with the interviewer's interactions and representations) an underlying personalized story of the self-enterprising self (Bamberg, De Fina, \& Schiffrin, 2007). I argue that narrative biographies are a productive methodological and analytical tool to investigate the nuances of students' perspective, due to the constant self-reflexivity demands that personal 'telling one's story' poses upon informants (Sabaté Dalmau, 2018).

\subsection{Context: The Catalan HE System}

Catalonia is a Catalan/Spanish bilingual society of about 7.5 inhabitants which is 
currently confronted with the challenges of the globalized new economy, concerning access to employability and to public tertiary education by young adult populations. The unemployment rate among people aged 16-29 in this place is $32.2 \%$ (OCJ, 2015, p. 11), and the cost of public BAs, in the case of Humanities, for instance, has risen by 172.25\% (OSU, 2013, p. 13), in a governmental privatization process linked to international job precarity and brain-drain (see Moyer, 2018).

Catalonia epitomizes the ways in which the neoliberalization of tertiary education has materialized in southern Europe, where the establishment of internationalization and Englishization plans is relatively new (Armengol, Cots, Llurda, \& Mancho-Barés, 2013), Under the socioeconomic circumstances described above, Catalan universities have started to follow governmental directives targeting 'Europeanization', presented as a requirement to 'accompany students to access the job marketplace' (Mas-Colell, 2002, p. 35) - that is, as an integral part of the students' academic/professional trajectories. They have also started to implement 'trilingualism' (Garrett, Cots, Lasagabaster, \& Llurda, 2012, p. 141). These three-language policies establish that all students should be competent in the two co-official languages of Catalonia (Catalan and Spanish, the most commonly used for teaching and administration; Vila, Bretxa, \& Comajoan, 2014), and, in the future, and with some controversy, in a third foreign language (FL), preferably English, upon completion of their degree (Generalitat de Catalunya, 2017).

\subsubsection{The Case of the UAB}

The Autonomous University of Barcelona, a top-ranked institution (in neoliberal indexes such as SIR WR, 2014), exemplifies how internationalization and Englishmediated 'multilingualization' through trilingualism unfolded in Catalonia. Defining itself as a 'university with an international outlook' (UAB, 2018), the UAB is a 
community of about 50,000 members, with $5.37 \%$ BA, $37.29 \%$ MA and $34.41 \% \mathrm{PhD}$ international students (ACP, 2018a).

At the time when this study was conducted (2011-2013), the UAB Plan for Languages was presented as 'a local and international reference for the construction and application of a model of governance for multilingualism in universities' (UAB Governing Council, 2011, pp. 2-4). It today defines English as an 'asset' and presents Englishization as a requirement for 'internationalization', as shown below:

'English has become the lingua franca of the international academic community and is increasingly used as an effective working language in the university [...]. It is therefore a key asset for the academic activity.' (UAB Governing Council, 2018, p. 3)

In 2013-2014, Catalan was the UAB's language of instruction at a BA level (69.8\%), followed at distance by Spanish (17\%) and by a 'third foreign language' (13.2\%) (GDLP, 2013, p. 26); basically, English (Estella, 2013, p. 45). This percentage of FLmedium instruction was $8.6 \%$ higher than the average for Catalan universities (ACP, 2015).

The four Combined Language Degrees in English in which the informants of this study enrolled were offered for the first time in 2009. They were a byproduct of the UAB internationalization and Englishization, and they exemplify the UAB's marketdriven investment in the implementation of new partial English-medium instruction (EMI) degrees with a semi-compulsory 'study abroad' experience. The CLDsE were presented as 'the most multilingual, new and unique educational offer in the entire Spanish state' and are now promoted as Multilingual Studies degrees which facilitate 'entering the workforce in any profession related to languages in any country of the European Union' (ACP, 2018b). 
In terms of management, the CLDsE depend on the collaboration between the English, French, Catalan, Spanish and Classics Departments. They offer partial EMI courses on English language and literature, and on the language and literature of any one of the other four languages. That is, almost half of the courses (105 ECTS) are taught in English, and the rest (105 ECTS), in French, Catalan or Spanish, with a choice of a 30-ECTS module in yet a third language (German, French, Italian, Galician or Basque). The twofold aim of CLDsE is to provide disciplinary knowledge (linguistics and literature content; e.g., 'Biological Bases of Language') and to teach these subject matters in a multilingual manner, ensuring, in turn, that students will attain the C2-level of English of the Common European Framework of Reference for Languages (CEFRL), upon completion of their degree.

During the academic year in which they were first offered as experimental Multilingual Studies (2009-2010), CLDsE registered 40 students. By the academic year 2013-2014, there were 111 new students and, overall, the number of $1^{\text {st }}-$ to- $4^{\text {th }}$-year students enrolled in a CLDsE rose to 327, with the average student profile being a 20year-old Catalan woman registered in the English and Spanish combination (see Table $1)$.

Table 1. CLDsE students' profile: No. of $1^{\text {st }}$-to- $4^{\text {th }}$-year students, and No. of new students by sex and age, per degree (2014).

[Insert Table 1 here]

Table 1 shows that the number of CLDsE students between 2010 and 2014 multiplied by eight, which was the highest number of enrollments in the Faculty of Letters. This success was due to the economic neoliberal efficiency, rationalization and redistribution of the language Departments' academic and material resources, aimed at 
counteracting the decrease in the number of enrollments in Philology degrees, at the UAB and elsewhere in Catalonia. All CLDsE courses were taken from the existing offer in the equivalent non-combined, one-language BAs that were losing students. They were taught by the same academic staff, previously hired by one of the five language Departments, and now 'flexibilized'. For example, the 'English and French' CLDsE offered courses taken from the 'English Studies' BA and from the 'French Studies' BA, and were taught by either English- or French-philology instructors.

\subsection{Methods, Data and Participants}

The data collected include: ${ }^{1}$

(1) The researcher's involvement in the third-year implementation of the CLDsE, in coordination with the UAB Faculty Board, as academic coordinator (2012-

2013). This provided access to (1) information concerning the Englishisation, as deployed in the curriculums of CLDsE; (2) students' socioeconomic/academic profiles and professional and language-learning expectations; and (3) demands, complaints, etc., concerning mobility programs' opportunities, third-language options, etc., gathered by the Student Delegation.

(2) The researcher's participant observation of 194 CLDsE students in the English classroom (2011-2013), as one of the two English instructors of their compulsory C1- and C2-level instrumental FL courses called 'Use of English 1' and 'Use of English 2', undertaken during the second and third academic years. Ethnographic fieldnote-taking was only systematized for the last year (20122013) when, after having developed an awareness of the students' degree of engagement with their university's internationalization and Multilingualization plans as their 'teacher', I started to collect pieces of evidence of students' 
attitudes, in the form of written documents (e.g. statements in opinion essays) or by noting down comments (e.g., in classroom debates) involving their perspectives on language-related or mobility matters, in what became a guiding 'ethnographic textbook' which comprised my 'close observation of and involvement with people' in that particular social setting, and which included 'the practices observed or experienced' as their lecturer (Jarzabkowski, Bednarek, \& Ley, 2014, p. 274).

(3) 30 audio-recorded semi-formal interviews eliciting life-narratives from students in 'Use of English 1'. These concerned the following narrative themes, provided by the researcher, which departed from above-mentioned 'ethnographic textbook' observations which informed the study: motivations to enroll in a CLDsE; multilingual resources (including expected/aspired linguistic trajectories); and short-/long-term mobility projects. They were collected during one of the three tutorial sessions conducted in English, in pairs, in the instructor's office (October 9, 2013). They lasted for 3:35 hours and were transcribed verbatim (see conventions in the Appendix). These tutorials accounted for $5 \%$ of the final mark of the course as 'active participation' (content and language were not assessed). At the end of each student's intervention, the instructor provided personalized feedback on grammar, lexicon, fluency and pronunciation. (These interviews complemented a study on an argumentative essay-writing task which also analyzed students' views on Englishization; Sabaté-Dalmau 2016).

(4) Informal follow-up email or Facebook messages sent by students, unsystematically, until May 2018, with autobiographical information concerning ‘life-after-university’ matters: post-BA mobilities, academic life, and (non)- 
employment at home and 'abroad'.

The selected group of informants was the third CLDsE promotion and consisted of 4 males and 26 females who had chosen the following combinations: English-French (12 students), English-Catalan (9), English-Spanish (5), and English-Classics (4). They were aged 20.3 months (in average). Seven were repeating students. The students' geodemographic and sociolinguistic background profiles were as follows. There were eight habitual Catalan-speaking students from the Balearic Islands (e.g. Alaior) who had moved to Barcelona to major in a CLDsE; three Spanish-speaking students who came from parts of Spain where Catalan is spoken (e.g. València), seven Catalan-speaking students who were raised in diverse Catalan-speaking regions located, at least, an hour from Barcelona (e.g. Palafrugell), and 12 students from big/medium-sized towns situated in dominant Spanish-speaking metropolitan areas near Barcelona (e.g. Molins de Rei).

The selection of this group responded to the fact that they were ready to develop personal narratives of experience concerning work/life trajectories interplaying with their views on English-mediated multilingualization: (1) They were involved in the piloting of these partial EMI programs and had responsibilities within the Student Delegation, showing a proactive orientation towards mobility and multilingualism; (2) they had gained relevant knowledge concerning the history, geographies and societies of English-speaking countries; and, finally, (3) they were on the midway of the degree and only had a few months to decide whether (and where) to apply for a semi-compulsory mobility program and to enroll in a third-FL module.

\section{Analysis}


CLDsE students narratively constructed geographic mobility as proof of one's educational advancement and success and of having the 'international' credentials required to find a job in the global 'language industry' (Duchêne \& Heller, 2012), which includes careers in teaching, tourism and translation. Thus, they approached study/stay-abroad mobility as a certifiable, accumulative and meritocratic 'employability resource' or 'asset' expected to materialize into profit; that is, into nearfuture (qualified) work in the aforementioned market segment (see Duchêne, 2016). In this section, I first focus on the interplay between narrated academic/professional transnational mobility and the linguistic trajectories linked to it, to argue that they are mutually constitutive. I secondly analyze the social meanings of more holistic 'elitist' (i.e. intellectually distinctive) life-mobilities, and then explore the cosmopolitan personhoods that emerge in students' personal-life storytelling, all of them addressed in the last part of this section, where I focus on the students' current aspirational trajectories.

\subsection{Fusing Academic and Professional Mobilities to Accumulate 'Multilingualism' Credentials}

All students' stories of geographic mobility at some point fused the boundaries between academic and early-career work trajectories. These, in turn, were mutually constitutive of how they territorialized their linguistic-mobility (for an analysis of intertwined geographic spatializations of FL learning see Gao \& Park, 2015). This discursive and material investment in educational/work mobilities interplaying with linguistic development was presented by students as a marker of individual progress and superior 
academic, professional and moral worth. In this sense, academic/work/ linguistic mobilities indexed a commitment to accumulate multilingual resources and to selfdevelop FL 'skills-sets' (Allan, 2016), signaling a neoliberalizing workplace-oriented disposition towards continued self-training and self-improvement, as illustrated by Lídia in Excerpt 1.

\section{Excerpt 1}

[Insert Table 2 here]

Lídia explains that her motivation for investing in a two-language degree was to become a FL teacher in secondary education (lines 3 and 7), for which an official MA is required (line 9). Lídia took it for granted that local high schools are hiring Englishspeaking staff (Catalan schools have started to implement 'plurilingualization' pedagogies by hiring instructors with a B2 English level; Codó \& Patiño, 2017). She, however, seeks to attain academic differentiation from 'regular' English teachers by self-attributing the command of two, not one, FLs (line 3).

Lídia's trajectory transcends the 'study abroad' experience and is envisioned as a flexible 'life abroad' project (line 11) consisting of work-oriented 'immersion' into the societies where her targeted lingua francas (presented as 'foreign languages') originated (line 12). Thus, Lídia invests in made-to-measure geographic mobility based on selfcapitalization of 'native-like' metacommunicative expertise which rests upon selfregimenting into (inner-circle) English and French standards, particularly concerning oral performance ('pronunciation'; line 12).

Lídia's narrative also shows that academic/early-career development is now mapped upon the 'transnational sphere', where language-related employability 
resources are represented as being developed 'globally' in a cumulative manner, in several 'local-ized' nation-state educational institutions. Lídia does not specify a particular emplacement but focuses on two 'countries' where her FLs are imagined to be spoken by 'natives': 'England' as the basis for attaining 'ordinary' communicative resources in English (line 14), and 'France' (line 17) for certifying added-value multilingual excellence (presented with the positivizing adjective 'fantastic'; line 18).

Excerpt 1 illustrates, too, that narratives of study/stay-abroad mobility contain a high degree of self-reflexivity revealing strategically planned projects aimed at carving a distinctive, exceptional identity for oneself (Codó, 2018a; Oliver \& O’Reilly, 2009). Examples of these included projected mobilities to 'global' places allowing for exposure to minimum two dominant foreign languages for 'multilingual competence' maximization, because mobility to English-speaking regions was seen as 'too mainstream'. Excerpt 2 illustrates the nuances of one of such individual/ized entrepreneurial-minded geographic trajectories, narrated by Rosa, who did her 3-month 'work-training' internship at Goethe-Universität (Frankfurt).

\section{Excerpt 2}

[Insert Table 3 here]

Rosa links her third-FL choice (line 1) to her professional mobility plan (she repeats 'work' in lines 6 and 12), in this case to Germany (lines 4 and 6), an 'economic power' (internal UAB leaflet for coordinators), where she sees herself as a teacher (line 14). Following the same nation-state framework as Lídia, Rosa links territoriality to an ethnolinguistic identity, when she uses 'German' (line 2) to name Germany ('country'; line 4). Her narrative on past work-training mobility interplays with her narrative on 
previous academic mobility in Denmark (line 18), presented with the qualifying adjective 'great' (line 18). This allows her to interactionally present herself as an initial Danish learner (line 21) as well as a student 'immersed' into the acquisition of disciplinary knowledge in yet another northern power, via 'native-like' English, through the construction of Denmark as a space with 'a high level in English' (lines 21-22). With this, Rosa self-ascribes a well-travelled identity with distinct neoliberal academic/workplace resources, including flexibility to change, certified 'work experience' and, notably, efficiency and proactivity towards multiple FL learning, further evidenced by the fact that she indirectly presents her English 'competence' as equally legitimate as that of 'German' high school instructors-to-be.

\subsection{Hypermobility as a Way of Being, Working and Enjoying Leisure}

Informants in Excerpts 1 and 2 fused language-related academic and professional mobility experiences. A third of the students even went beyond this and narrated 'mobility' as a fused way of learning, working and enjoying leisure, with more holistic lifestyle projections (see Cohen, Duncan, \& Thulemark, 2015). This is illustrated in Excerpt 3 by Miquel, who locates geographic mobility in the 'transnational arena' but, unlike Lídia and Rosa, without constructing 'transnationalism' as a sequence of visits to compartimentalized nation-states (see, also, Garrido, 2019, in this volume).

\section{Excerpt 3}

[Insert Table 4 here]

Miquel emphasizes that he is already highly mobile. He departs from the nationstate/local framework ('Spain', where he locates himself; line 4), and then maps intense trajectories around 'Europe' (with large-quantity determiners: 'almost every' and 'a lot 
of'; line 4). He then moves his space-narrative 'outside Europe', to a mixture of countries, continental regions and continents, in an unfinished list ('Asia', 'South America'; line 6, and 'Australia'; line 8), which may be read as 'the world', as he previously mentions, via repetition (line 2) (his use of 'California' (line 5) was motivated by my insistence on him naming one place, earlier on in the tutorial).

He takes Erasmus mobility as his point of departure (line 1) but then links it to an underdefined journey (he names 'another country'; line 3) based on 'learning', a verb in the continuous form, highlighting process and non-finiteness, employed three times (lines 2-3). This 'learning' does not focus on disciplinary knowledge but on social life outside academia ('behavior'; line 3). With this, Miquel illustrates what Hannerz (1996, p. 103) calls an aesthetic and intellectual willingness and capacity to engage with cultural/linguistic 'Otherness'. This is central to geographic mobility, where leisure/holiday 'traveling' (line 1) is equated to 'learning' (lines 2-3) and is narrated as a matter of personal growth - a somehow exoticized self-discovery, as opposed to the (more superficial) tourist experience.

Further evidence of this was provided by Lídia's tutorial partner, Gemma (20; studying English-French; from Majorca), who claimed: 'I would like to do a kind of Erasmus of living'. Similarly, Roc (20; studying English-Classics, from Majorca), replied to my question on why he chose 'America' for a stay abroad by stating: 'it attracts me $[\ldots]$ the culture the people the lifestyle is different from here,' detaching mobility from academia or work and linking it to inner-Self attraction to newness, difference and contrast (see, also, Codó, 2018b). Note, too, that European spaces are avoided in favor of 'the world', unless they are strangerized as providers of atypical experiences. 
Excerpt 3 also indicates that emplacement choice may be discursively detached from FL-learning motivations, in narratives that do not draw solely on nativist conceptions of languages (in opposition to what was shown in Excerpts 1 and 2). For instance, Roc did not mention, and Miquel did not foreground, English-language learning as one of the reasons for choosing US spaces. Motivations to move to Englishspeaking regions other than FL-improvement included consumption of material culture (e.g. 'summer festivals' and 'music') and natural scenery and heritage experiences (e.g. 'sightseeing' and 'landscapes'). In fact, a third of students disaligned from nativist discourses and legitimized hybrid multilingual practices with traces of local/distant codes materialized in global English, in academic and work realms, and in non-Englishspeaking regions. This linguistic legitimization of one's 'non-perfect' English competence is illustrated by Sara in Excerpt 4.

\section{Excerpt 4}

[Insert Table 5 here]

Sara presents her stay abroad as having two aims: she went to an English-language school to certify her B2 English level (as she explained earlier on) and to work as an aupair (lines 2 and 6) in Italy (line 1), which is not officially English-speaking. Sara equates nursery/care services ('babysitting'; line 5) to 'teach [...] English' (lines 1 and 2), self-ascribing linguistic resources to be a FL teacher for children in a multicultural environment, implicitly presenting her host Italian family as having legitimized such linguistic employability resource. Sara's identity as a successful non-native teacher (line 10) is narratively achieved, too, with the mobilization of Australian relatives' evaluation 
of her English as apt (with 'it could be worse'; line 11), presented via emotion adjectives denoting self-satisfaction and accomplishment ('nice': line 8, and 'very proud'; line 13). While she follows nativist conceptions of English (Australian, not Italian, relatives are presented as language judges), she emphasizes that this event occurred 'only' two weeks after starting her English course, embodying an already proficient self. In the ethnographic textbook, I could historicize Sara's linguistic trajectory at the UAB. I found that she had to repeat the first-year B2-level course and simultaneously manage the C1-level one. As her instructor, I interpreted her narrative as a way of showing extra 'effort' to invest in (non)-formal learning.

\subsection{Neoliberalizing Identities: Self-Made Cosmopolitan Lifestylers}

In this section I focus on the identities that emanate from the narratives of linguistic academic/work-related mobility analyzed above, based on projections of a desirable Self with 'transnational-life competences' which are marketable in European workplaces. I argue that these identities follow the tenets of neoliberalism because they draw on modern 'cosmopolitan lifestyles' (defined in Hannerz, 1996, 2004) and hypermobile elite multilingual Selves. That is, they are self-ascribed identities where students engage in a socially 'glamorized' intense travelling linked to intellectual elitism (Cohen \& Gössling, 2015) by projecting ‘openminded' yet ego-centered, ‘civicmorality' personhoods (Del Percio, 2018), as illustrated by Oriol in Excerpt 5.

\section{Excerpt 5}

[Insert Table 6 here] 
Encouraged by the researcher, Oriol presents his English-language resources as exceptional, locating his proficiency in childhood/early adolescence (lines 2 and 5-6), emphatically ('pretty young'; line 6). He suggests he 'grew up' with English (without remembering the process exactly), though with dedicated effort ('reading a lot'; line 12). This almost-innate easiness makes his interpersonal communication outstanding (see 'easier'; line 13), as seen, too, when he opposes his 'gift' for English-language development to that of 'people' who followed similar formal FL-instruction trajectories but attained a lower level (lines 8 and 11). This 'feel' for languages is revealed through the terrain of basic feelings and desires ('really really fond'; 'interested'; line 13). This was also encountered in the use of 'love' by Miquel, or of 'my passion', by Lídia, employed to refer to FLs in her personal blog, as a narrative tool to embody self'multilingualization'.

In Excerpt 5, Oriol later presents his professional plans. He carves a career for himself based on 'life-on-the-move' (mystified with 'travelling a lot as a career'; line 18), with laughter, which may reveal his awareness of the non-orthodoxy behind inhabiting extreme mobility as a way of living. His work projections keep moving the narrative scheme from singularity to standardness, through extensive hesitation ('I don't know'; lines 20-23, concessives like 'but'; lines 21, 23, 26, 27; and fillers like 'well', 'you know', 'will see'; lines 16, 20, 23 and 27). He navigates between his romanticized aspirations to become a writer (line 20) and his realistic chances to work in 'whatever' (line 23) regular language-industry niches, presented in a list of professions with 'translating or teaching' (line 26), which minimize the differences between these careers, to finally focus on one: 'teaching' (line 27).

He mobilizes this change of narrative scheme concerning future employability by playing with interactional dichotomies, opposing the unquestionability and 
determination to develop his wished-for job as a 'writer' - as seen in 'of course' (line 20) - with nuance about whether it can be materialized, given the unnarrated constraints of the new economy, which is seen in: 'wouldn't love' (line 21) or 'not a very appealing idea' (line 23), 'not the best in the world at all' (lines 23-24). In a second narrative move, he thematizes 'teaching/teacher', constructed as being imposed by market conditions ('it is not that I want'; line 27), but later contradictorily embraced and represented as fulfilling (with 'like'; line 27, and 'opportunity'; line 29).

The self-ascription of a 'teacher' identity is conducted by foregrounding the altruistic moral values of the profession (with 'help people understand'; line 29), and by de-focusing the agents involved (unnaming students/learners with the use of 'people'; lines 15 and 17, and unnaming, too, content/curricula to be taught, with the use of 'things'; line 31). Both professions involve some literary knowledge. However, the literature component only emerges with the 'writer' profession, not the 'teacher' profession. Besides, the category 'writer', which implies a fusion of the self/work persona, is mobilized with the verb 'succeed' (lines 20-21), which involves competition among intellectual elites. The presentation of a prospective Self with the professional identity 'teacher', by contrast, is embodied by Oriol only by orienting it towards 'civic' personality talents, such as transmitting knowledge to the less (physically, educationally or intellectually) mature (lines 29 and 31), for which he is especially successful (note that 'I'm quite good at it', in line 32, is only mitigated with other-ascription, with 'people tend to say'; line 31). Both for 'writer' and 'teacher', Oriol highlights his 'proper' moral values: in the first case, by presenting his work aspirations as a difficult journey requiring tiresome, dedicated investment, mobilizing the culture of effort; in the second case, by 'doing good' through sharing his gifts for transmitting knowledge. In both cases, he acts as an exemplary social agent, providing further evidence that 
'mobility itself can become indexical of an ideal neoliberal subject' (Gao \& Park, 2015, p. 81).

\section{4. 'Life-after-graduation' Trajectories: The Centrality of Future}

\section{Educational/Professional/Leisure mobilities}

By May 2018, Lídia and Rosa had become FL highschool teachers, and Oriol, a university research assistant, semi-professional writer and literary critic. Other informants had enrolled in various Applied Linguistics/Literature MAs, in Catalan and European universities (e.g. Manchester Metropolitan and University College London). Many others had gotten temporary jobs in tourism or language schools (e.g. in theme parks or as 'English-speaking' babysitters), in Catalonia; and the rest were working in non-qualified services-sector in cosmopolitan cities (e.g. Vienna, Aarhus, Munich), silencing lived experiences of under/non-employment (see, also, Moyer, 2018).

They all kept self-ascribing lifestyle identities based on highly mobile, Englishmediated multilingual ways of being. This was clearly seen during my postethnographic follow-up research, where I could gather narrative statements which read 'I'm very happy here in England and trying to travel as much as I can' (Bernat, studying English-French; from Majorca, now unemployed and studying English in Bournemouth; aged 24; email sent to the researcher 24/05/2017) [Catalan original: 'Em trobo molt a gust a Anglaterra $i$ intent viatjar al màxim']. It could also be observed in many testimonials posted by former CLDsE students on the official MA in Foreign Language Teaching, where Lídia, for instance, stated (prior to obtaining her teaching positions) that the CLDsE had made 'the dream to become FL instructor come true' [...] 'they have not only reassured my love for these languages' [...] 'They also helped me to 
discover my great passion for their literature and culture' (Lídia, former English-French student; from Girona, then aged 22; online blog post in the official MA's website for the academic year 2016/17) [Catalan original: 'que poguessin fer realitat el meu somni de convertir-me en professora de llengües estrangeres' [...] 'No només han fet més que reafirmar el meu amor per aquestes llengües' [...] 'també em van ajudar a descobrir la meva gran passió per la seva literatura i cultura '].

These snapshots of 'life-after-graduation' trajectories, provided by way of summarizing the analyses provided in this section, further evidence that educational/professional/leisure mobilities have gained an unprecedented centrality in the life projects and identities of university students, who now keep investing in mainstreamed positive discourses on life-on-the-go 'mobility' and on elite 'multilingualism' competence, both unproblematically seen, in a widely circulated neoliberal master narrative of 'international' experience and 'multilingualized lifestyler' Self, as unique educational, employability and personhood resources and assets.

\section{Conclusions}

From a critical sociolinguistic ethnographic approach to internationalization policies and multilingualization plans in Southern European universities, this paper has focused on the students' perspectives on the mercantilization of HE; particularly, on the marketization of the studenthood cohort. To this aim, I have analyzed the attitudes and identities mobilized by a group of 30 students undertaking an English-mediated Multilingualism degree in bilingual Catalonia in order to understand the extent to which, and the reasons why, they invest in neoliberal educational and economicist linguistic rationalities and on market-driven personhood profiles. 
The overall results have shown that informants follow the institutional regimes of the EHEA guided by the globalized new economy, which markets them as selfenterprising workers-to-be in the competitive language industry. They embody unique cosmopolitan lifestyles based on the 'multilingualized' Self which emerges in an overarching story-telling that has become the discursive terrain whereby they carve specific 'narratives of difference' (Gao \& Park, 2015, p. 88). These are used to reflexively account for, and give coherence to, one's individual choices, life-conditions and future imaginings, in times of socioeconomic and political uncertainty.

In this regard, I suggest that the narrative autobiographies (accompanied with a long-term ethnographic fieldwork) analyzed in this group unpack the ways in which philology students invested in 'Europeanization' employability profiles which draw on a meritocratic logic that assumes that access to employability resources depends on one' readiness to optimize, flexibilize and 'engineer' oneself (Del Percio, 2018) - in this case, through attitudes that denote self-training into hegemonic language hierarchies and transnational work orders. I argue that this occurs with some degree of ambivalence, as seen when informants construct stay/life-abroad projects both as being enforced and as being pleasure (as a requirement and as a passion) and when they glide through understandings of multilingualism as the cumulative sum of native-like, monolingual FL certificates and as fluid self-made repositories of legitimate or delegitimate effective local/global Englishes.

In this sense, I claim that they inhabit academic, professional and linguistic global-citizenship identities excelling as competitive, qualified workers-to-be in the transnational arena, which fuse their aspirational educational/professional and leisure trajectories in the socialization spaces that they inhabit. I suggest that these contradictions are the basis upon which students carve an intellectual distinction based 
on the self-ascription of exemplary neoliberal worker/Self moralities and ethical citizenship values.

All in all, I conclude that these cosmopolitan lifestyling narratives sustain global socioeconomic structures of competition and hierarchizations which are no longer based on the principles of welfarean education but on the principles of the market. This contributes to the analysis of contemporary entrepreneurial-minded, cosmopolitan projections of the Self as an advantaged elite, in youth identity practices which, on the basis of mercantilized mobility and language-capitalization opportunities, point to newer forms of creating socioeconomic and linguistic distinction and, therefore, stratification in public university systems of southern Europe.

\section{Acknowledgements}

I'm thankful to the informants who participated in this study, as well as to Michael Kennedy, for his help with it. Many thanks too, to Maria Rosa Garrido-Sardà and for the two reviewers for their insightful feedback on previous versions of this article. Any shortcomings are mine.

\section{Disclosure statement}

No potential conflict of interest was reported by the author.

\section{Funding}

This work was supported by the Spanish Ministry of Economy, Industry and Competitiveness; under Grant MINECO. FFI2016-76383-P; and the Catalan Ministry of Economy and Knowledge under Grant AGAUR 2017 SGR 1522. 


\section{ORCID}

0000-0001-6058-7227

\section{References}

ACP. (2015). La UAB en xifres [UAB in numbers]. Retrieved from

http://www.uab.cat/web/coneix-la-uab-cei/la-uab-en-xifres-

\section{5.html}

ACP. (2018a). The UAB in figures. Retrieved from: http://www.uab.cat/web/about-theuab/the-uab/the-uab-in-figures-1345668682835.html

ACP. (2018b). Bachelor's Degree in English and French Studies. Retrieved from: http://www.uab.cat/web/estudiar/ehea-degrees/general-information$\underline{1216708259085 . h t m l \text { param } 1=1264578113763}$

Allan, K. (2016). Going beyond language: Soft skill-ing cultural difference and immigrant integration in Toronto, Canada. Multilingua, 35, 617-647.

Armengol, L., Cots, J. M., Llurda, E., \& Mancho-Barés, G. (Eds.) (2013). Universitats internacionals i plurilingües? Entre les polítiques i les pràctiques a les universitats de Catalunya [International and plurilingual universities? Between policies and practices in Catalan universities]. Universitat de Lleida: Edicions de la Universitat de Lleida.

Bamberg, M., De Fina, A. \&, Schiffrin, D. (Eds.). (2007). Selves and identities in narrative and discourse. Amsterdam: John Benjamins.

Block, D. (2018). Some thoughts on education and the discourse of global neoliberalism. Language and Intercultural Communication, 18(5), 576-584. 
Codó, E. (2014). Cosmopolitanism, mobility and multilingualism: New discourses for new identities? In R. Casesnoves-Ferrer, M. Guinjoan, \& N. Gavaldà Ferré (Eds.), Ens queda la paraula: estudis de lingüística aplicada en honor a M. Teresa Turell [We will always have words: Applied linguistics studies in honor of M. Teresa Turell] (pp. 153-169). Barcelona: Institut Universitari de Lingüística Aplicada.

Codó, E. (2018a). Lifestyle residents in Barcelona: a biographical perspective on linguistic repertoires, identity narrative and transnational mobility. International Journal of the Sociology of Language, 2018(250), 11-34.

Codó, E. (2018b). Language policy and planning, institutions and neoliberalisation. In J. W. Tollefson \& M. Pérez-Milans (Eds.), The Oxford handbook of language policy and planning (pp. 467-484). Oxford: Oxford University Press.

Codó, E. \& Patiño, A. (2017). CLIL, unequal working conditions and neoliberal subjectivities in a state secondary school. Language Policy. DOI: 10.1007/s10993-017-9451-5.

Cohen, S. A., Duncan, T., \& Thulemark, M. (2015). Lifestyle mobilities: The crossroads of travel, leisure and migration. Mobilities, 10, 155-172.

Cohen, S. A., \& Gössling, S. (2015). A darker side of immobility. Environment and Planning A, 47(8), 111-134.

Coleman, J. (2006). English-medium teaching in European higher education. Language Teaching, 39, 1-14.

Deem, R. (2001). Globalisation, new managerialism, academic capitalism and entrepreneurialism in universities: Is the local dimension still important? Comparative Education, 37(1), 7-20. 
Del Percio, A. (2018). Engineering commodifiable workers: language, migration and the governmentality of the self. Language Policy, 17(2), 239-259.

Duchêne, A. (2016). Investissement langagier et économie politique [Language investment and political economy]. Langage \& Société, 3(157), 73-96.

Duchêne, A. \& Heller, M. (2012). Language in late capitalism: pride and profit. London: Routledge.

Estella, M. (2013). 'Per què en diem tercera llengua si volem dir anglès?' Apunts sobre multilingüisme i internacionalització a la Universitat [Why do we say third language if we mean English?]. In L. Armengol, J. M. Cots, E. Llurda, \& G. Mancho-Barés (Eds.), Universitats internacionals i plurilingües? Entre les polítiques i les pràctiques a les universitats de Catalunya (pp. 45-53). UdL: Edicions de la UdL.

Fairclough, N. (2006). Language and globalization. London: Routledge.

Flubacher, M., Duchêne, A., \& Coray, R. (2018). Language investment and employability. The uneven distribution of resources in the public employment service. Switzerland: Palgrave.

Gao, S., \& Park, J. S. Y. (2015). Space and language learning under the neoliberal economy. L2 Journal, 7(3), 78-96.Garrett, P., Cots, J. M., Lasagabaster, D., \& Llurda, E. (2012). Internationalisation and the place of minority languages in universities in three European bilingual contexts: A comparison of the student perspectives in the Basque Country, Catalonia and Wales. In A. Yiakoumetti (Ed.), Harnessing linguistic variation to improve education (pp. 139-166). Oxford: Peter Lang.

Garrido, Maria Rosa (2019). Language investment in the trajectories of mobile, multilingual humanitarian workers. International Journal of Multilingualism. 
Generalitat de Catalunya. (2017, 6 July). Proposal to postpone requirement for bachelor's degree students to obtain B2 level by graduation approved. Generalitat de Catalunya. Universitats i Recerca. Retrieved from: http://universitatsirecerca.gencat.cat/ca/detalls/noticia/Aprovadamoratoria4any $\underline{\mathrm{sB} 2}$

GDLP. (2013). Informe de política lingüística 2013 [Language policy report 2013]. Barcelona: General Directorate for Language Policy. Generalitat de Catalunya. $\begin{array}{ll}\text { Retrieved } & \text { from }\end{array}$ http://llengua.gencat.cat/web/.content/documents/informepl/arxius/IPL 2013.p $\underline{\mathrm{df}}$

Hannerz, U. (1996). Transnational connections. culture, people, places. London: Routledge.

Hannerz, U. (2004). Perspectives toward cosmopolitanism as a cultural resource. Interdisciplinary Cultural Studies, 8, 5-17.

Jarzabkowski, P., Bednarek, R., \& Ley. J. K. (2014). Producing persuasive findings: Demystifying ethnographic textwork in strategy and organization research. Strategic Organization 2(4), 274-287.

Kroskrity, P.V. (ed.) (2000). Regimes of language: ideologies, polities, and identities. Santa Fe, NM: School of American Research Press and James Currey Ltd.

Llurda, E., Doiz, A., \& Sierra, J. M. (2015). Students' representations of multilingualism and internationalization at two bilingual universities in Spain. In A. H. Fabricius, \& B. Preisler (Eds.), Transcultural interaction and linguistic diversity in higher education: The student experience (pp. 92-115). Houndmills: Palgrave Macmillan. 
Martín Rojo, L. (2019). The ‘self-made speaker': the neoliberal governance of speakers.

In L. Martín Rojo, \& A. Del Percio (Eds.) Language and Neoliberal

Governmentality (pp. 162-189). London: Routledge.

Mas-Colell, A. (2002). Els camins europeus de Catalunya: La Universitat [Catalonia's

European paths: the university]. Barcelona: Generalitat de Catalunya.

Departament d'Universitats, Recerca i Societat de la Informació.

Moyer, M. (2018). English in times of crisis. Mobility and work among young

Spaniards in London. Language and Intercultural Communication, 18(4), 424435.

OCJ. (2015). Situació laboral de les persones joves a Catalunya. 4t trimestre de 2014

[Labor situation of Young people in Catalonia. $4^{\text {th }}$ semester of 2014].

Generalitat de Catalunya. Direcció General de Joventut. Retrieved from

http://ejoventut.gencat/web/.content/e-

joventut/recursos/tipus de recurs/documentacio/arxiu/document/informes epa

IInforme EPA 4rt trimestre 2014.pdf

Oliver, C., \& O’Reilly, K. (2009). A Bourdieusian analysis of class and migration: habitus and the individualizing process. Sociology, 44(1), 49-66.

OSU. (2013). El preu de la carrera. Preus universitaris 2013-2014 i anàlisi de l'evolució del preu total dels estudis [the Price of the BA. University prices 2013-2014 and analysis of the overall increase of the price of studies]. Barcelona:

Observatori del Sistema Universitari. Retrieved from http://www.observatoriuniversitari.org/Fitxers/CostCarreres2013/Carrera.pdf

Piller, I., \& Cho, J. (2013). Neoliberalism as language policy. Language in Society, 42, 23-44. 
Pujolar, J., \& Puigdevall, M. (2015). Linguistic mudes: How to become a new speaker in Catalonia. International Journal of the Sociology of Language, 231, 167187.

Sabaté-Dalmau, M. (2016). The Englishisation of higher education in Catalonia: a critical sociolinguistic ethnographic approach to the students' perspectives. Language, Culture and Curriculum, 29(3), 263-285.

Sabaté Dalmau, Maria. (2018). Exploring the interplay of narrative and ethnography: A critical sociolinguistic approach to migrant stories of dis/emplacement. International Journal of the Sociology of Language 2018(250), 35-58.

Schieffelin, B.B., Woolard, K.A., \& Kroskrity, P.V. (eds). (1998). Language ideologies: practice and theory. Oxford: Oxford University Press.

SIR WR. (2014). Scimago institution rankings World Report 2014. Retrieved from http://www.scimagoir.com/institution.php?idp=35800

UAB. (2018). Internationalisation. Retrieved from: http://www.uab.cat/web/about-the$\underline{\text { uab/the-uab/internationalisation-1345687519024.html }}$

UAB Governing Council. (2011). Plan for languages 2011-2015. Retrieved from http://www.uab.cat/Document/737/609/CampusPlaLlengues20112015_en.pdf

UAB Governing Council. (2018). Plan for languages 2016-2020. Retrieved from https://ddd.uab.cat/pub/docins/2016/175730/camplallenuab_a20162020iENG.pdf

Vila, F. X., Bretxa, V., \& Comajoan, L. (2014). ¿En qué lenguas se hace ciencia? La gestión del multilingüismo en el Parc Científic de Barcelona [what lanaguges is science conducted? The management of multilingualism in Barcelona's Parc Científic]. Revista Internacional de Organizaciones, 13, 111-134. 


\section{Bionote}

Maria Sabaté-Dalmau (MA in Linguistic Anthropology, UofT; MA and PhD in English Philology, UAB) is visiting professor at the Universitat de Lleida (Catalonia), where she conducts critical sociolinguistic ethnographic research on mobility, multilingualism, and transnational linguistic identities. She is a board member of the Catalan Sociolinguistics Society. Her work includes Migrant Communication Enterprises: Regimentation and Resistance (Multilingual Matters, 2014).

\section{Appendix: Transcription system}

\section{Conventions}

@Bck: Background information concerning participants (CLDsE, place of birth, age and topic)

\%com: $\quad$ contextual information about the previous utterance

\%tra: free translation of the turn for languages other than English

$+^{\wedge} \quad$ quick uptake/latching

\# $\quad$ pause

[>] overlap follows

$[<] \quad$ overlap precedes

$[/ /] \quad$ reformulation

$<>\quad$ scope

: lengthened vowel

((Follows narrative)) Turns omitted for space or confidentiality constraints

\section{Intonation}


end-of-turn falling contour

? end-of-turn rising contour

! end-of-turn exclamation contour

,$- \quad$ intra-turn fall-rise contour

Notes

1. No confidential information has been displayed. The informants' data was gathered with informed consent. All names are pseudonyms. 